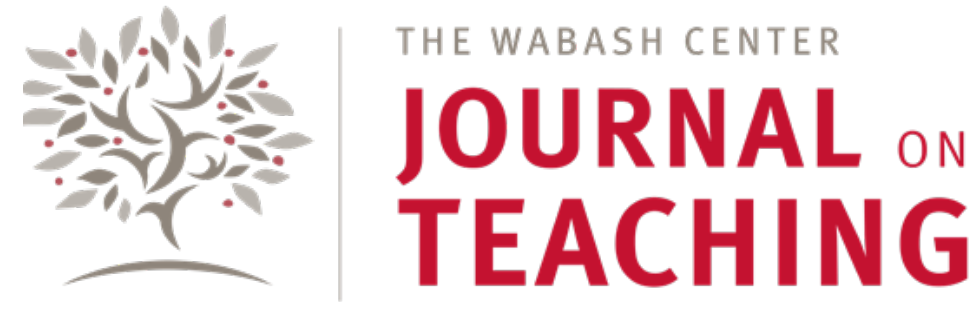

ARTICLE

\title{
Living and Teaching When Change is the New Normal: Trends in Theological Education and the Impact on Teaching and Learning
}

Frank M. Yamada

Association of Theological Schools and the Commission on Accrediting

\begin{abstract}
Theological education is currently undergoing significant changes. These changes are rooted in broader trends within the changing landscape of North American religion and higher education. This article surveys these larger shifts and explores their impact on the Associaton of Theological Schools (ATS), particularly in the changing financial/organizational model of schools, in the educational models and practices, and in the changing demographics of ATS student bodies. These trends point to significant themes that will characterize teaching and learning strategies for the future.
\end{abstract}

KEYWORDS

change, ATS schools, broader trends in religion and higher education

Change. It is a commonly used word in circles of theological education and in higher education. My journey in theological education is not unfamiliar to the forces of change that many theological schools are confronting; in fact, it illustrates many of the dynamics that schools are facing. My first teaching job stretched for nine years at an Episcopal seminary in the Chicago area. The school fit the image of what one would imagine for a residential Episcopal school through the last decades of the twentieth century. There was teaching, learning, and Anglican formation. There was a lot of worship. In fact, daily worship was part of the core experience for students, faculty, and the broader seminary community. There was antiracism work and cultural transformation, and there was a steady and troublesome decline in the student population. There were no online courses. None of these factors would have seemed unremarkable within the broader ecology of The Association of Theological Schools during this period. However, my experiences within this seminary community would change abruptly in the 2008-2009 academic year; and this change can be summed up in minutes and seconds, 13:45 to be precise.

In the spring of 2008, before the stock market crash, a specially commissioned committee comprised of board members, staff, and faculty, completed their work that resulted in a recommendation to the full board. The school had been facing significant enrollment and financial challenges, and this committee weighed the options in front of the seminary. I served on this committee as a junior faculty person. I was in attendance at the spring board meeting because of two decisions that were going to be made. The first passed unanimously. I was granted tenure and promotion. This was a notable moment for the seminary, since I was the first person of color to receive tenure in the 150-year history of the school. I remember that the bishop of Michigan, an African American, was in tears. The next item on the board's docket was the decision related to the special committee's report. The board had already read the report and had met by phone multiple times prior to its fall meeting. The item on the 
agenda was for the board to take official action. I set the stop watch on my smart phone. In exactly thirteen minutes and forty-five seconds, after a brief description of the action to be taken and a time of solemn prayer, the board made the decision to declare financial exigency and terminate the faculty (the faculty would be retained for another year with a reduced teaching load). I am almost certain that this is the shortest time from tenure to termination in the history of the academy.

Later that summer, I began teaching and directing a center for Asian American ministry at a Presbyterian seminary located on the south side of Chicago. This school, which was founded in the early nineteenth century, had built a large endowment over the decades and had relocated in the 1980 in order to better serve urban populations within the city. Over two-thirds of the seminary's students were non-residential commuters. Most were persons of color serving communities of faith on the west and south sides of Chicago. Though there were only a few online courses being offered, the school was able to reach its urban student population by offering many of its courses in the evenings.

In the fall of 2008, after the crash of the stock market, the seminary's president called a special meeting, in which she shared the news of how the market's declines had impacted the seminary's endowment. The endowment had lost over 20 percent of its total value. Significant budget cuts and a dramatically different financial plan were proposed to address the challenges. Even with this sharp decline in financial resources, the school still possessed a large endowment. As news of how other schools were faring during the economic recession began to spread, it became clear that we were living in a new era of vulnerability for theological education. These financial episodes were not isolated incidents. We were living in a new reality, a changed world.

Personal anecdotes aside, there are data and pieces of evidence that demonstrate that my personal stories are rooted in deeper trends that have been at work within theological schools over the past twenty to thirty years. Themes include: mergers; enrollment and financial challenges; the need for new educational models (including the role of digital technologies); the changing nature of faculty work; increased attention on student formation; and the changing nature of student demographics. The forces behind these winds of change come from both broader trends in higher education and the changing landscape of religion in North America. At The Association of Theological Schools (ATS), we see evidence of these changes in every aspect of a school - in its financial and organizational model, in its educational delivery and practices, and in the student bodies whom the school educates.

In my first year as Executive Director at the ATS, I went on a listening tour. Through various meetings and gatherings, I was able to engage administrators and faculty from 86 percent of what was, at the time, 270 member schools. ${ }^{1}$ The testimonies from these theological educators pointed to the broad forces impacting theological education named above. The consistent refrain within these gatherings was that schools are changing rapidly and profoundly, perhaps in unprecedented ways; and while these challenges appear daunting, this environment is also generating creativity among schools' faculties. There is no dominant approach emerging among these trends. Ted Smith sums up well the thoughts of my predecessor at ATS: "Daniel Aleshire has said that in these times we are not moving from one model of theological education to another, but from one model to many others. Pluralism is the time signature of the present moment” (Smith, Jewell, and Kang 2018, 9).

These changes within theological education will have obvious effects on how teaching and learning is evolving in theology and religion in the twenty-first century. The purpose of this article is to highlight these broader trends in order to provide a deep context of understanding for the current practices within theological schools. My proposal for trajectories of teaching and learning within this environment is admittedly modest, but it emerges deductively from the institutional and social forces at work within North American education and religion. ${ }^{2}$

\section{Changes in North American Religion}

The religious landscape of North America is changing. The often cited report from the Pew Research Center (2015) demonstrates dramatic shifts in the makeup of religion in the United States. Some of the key findings from this report include:

- While seven in ten persons in the U.S. consider themselves to be Christian, that number has dropped by almost 8.5 percent in a seven year period.

\footnotetext{
1 In 2019, the current total of member schools within the ATS is 276. This number includes accredited schools and schools that are candidates for accreditation.

2 On the changing shape of North American religions, see Chaves (2017), Hudnut-Beumler and Silk (2018). For the Canadian context see Clarke and Macdonald (2017).
} 
- $\quad$ These declines are more dramatic for mainline Protestants (-3.4 percent) and Roman Catholics (-3.1 percent) than among evangelical Protestants (-0.9 percent)

- The religiously unaffiliated have increased by over 19 million, up 6.7 percent between 2007-2014.

- Millennials make up the greatest share of the religiously unaffiliated. Thirty-five percent of adult Millennials do not align themselves with a religious group, and that number is growing. ${ }^{3}$

- $\quad$ Following broader U.S. demographic trends, U.S. Christianity is becoming more racially and ethnically diverse. "Racial and ethnic minorities now make up 41 percent of Catholics (up from 35 percent in 2007), 24 percent of evangelical Protestants (up from 19 percent) and 14 percent of mainline Protestants (up from 9 percent)." (Pew Research Center 2015)

These data lead to an undisputed conclusion - the nature and character of U.S. Christianity and religion, in general, is changing dramatically. These changes can be seen most in the declining influence and attendance within particularly mainline Protestant and Roman Catholic churches in the United States. ${ }^{4}$ Over the past decade, the share of Christians who are evangelicals has remained relatively stable; but that share is also down from its peak of 29.9 percent of the population in 1993 to 22.5 percent in 2018. ${ }^{5}$ In Canada, there are similar trends, though clear markers and data that suggest that the movement toward secularization has been more pronounced there, leading the authors of a recent study to argue that "Canadian society is entering into a new era, a post-Christian era." ${ }^{6}$

These data point to broader changes in the religious landscape that are captured anecdotally at the local level where congregational attendance is down and "graying" (Hudnut-Beumler and Silk 2018), in which local communities of faith struggle to bridge generational gaps, and where religion's role in U.S. society is having decreasing influence in matters of our common life and the public good. The time where the movers and shakers in a community were church-goers and bound together through common commitments and values has been gone for decades. Denominations and religious traditions are becoming less centralized, and, are instead, increasingly regional and local in their influence. While many scholars continue to argue about the nature and extent of the decline of Christianity in the U.S., it is clear that we are moving into a period where religion's role in the shaping of community norms and policies has changed irreversibly.

\section{Changes in Higher Education}

Higher education has also been experiencing tectonic shifts within the past two to three decades. Several years of enrollment declines have led to an increasing number of colleges that have closed or merged. Digital technologies have changed how many schools deliver their educational mission, although distributed learning has not turned out to be the disruptive innovative force that some predicted. ${ }^{7}$ The rising price tag of a high fixed-cost model of education has put strain on university boards while dramatically increasing the amount of student debt. For-profit education posed significant threats to student markets in which students sought lower cost alternatives to traditional degree programs. Moreover, the relevance of a college education has been increasingly called into question, citing the well-rehearsed gap between what students have learned and the skills the labor market demands.

Of course, all of these factors impact the students who consider graduate school generally and graduate-level theological education specifically. If the Millennial bubble in higher education - which led to the growth and expansion of colleges and universities over the past three decades - has deflated, and those same students are increasingly unaffiliated when it comes to religion, the impact on seminary enrollments seems inevitable. Moreover, mounting debt accumulated by students prior

\footnotetext{
3 Among older Millennials, those born between 1981-1989, the percentage of the religiously unaffiliated has grown from 25 percent of the group to 34 percent, an increase of 9 percent in seven years. For a more detailed discussion of Millennials and religion, see Lipka (2015).

4 For the full report, see Pew Research Center (2015).

5 These data come from General Social Survey (GSS) as reported in a recent report from Christianity Today (Burge 2019).

6 Clarke and Macdonald look at census and membership data from denominations in their study. They argue that "(d)ecline in Christian affiliation, membership, and participation started in the 1960 s and has picked up pace rapidly since then" $(2017,11)$. Similar to the U.S. data, the one group that has grown during this time is the No Religion group, which went from 4 percent in 1971 to almost 25 percent in 2011 (Clarke and Macdonald 2017, 11).

7 Clayton Christensen (2011) argues that online education has the potential to be a disruptive innovation within higher education. At various public lectures, he has predicted that 50 percent of universities and colleges will close within the next ten to fifteen years. This has not proven to be the case. Online education, however, has proven to be a more sustaining innovation, opening up enrollment streams and providing education at lower cost to students.
} 
to their attending graduate theological education has produced additional pressure on a system that is already financially strained.

There is another way to frame these larger trends. Theological education sits at the intersection of the changes that are happening in religion and higher education in the U.S. and Canada. This is why it should not surprise us when a dominant theme of feedback that we hear from ATS schools is change. However, there is something particular and unique about the changes that we are experiencing. Perhaps we are living in an "Age of Accelerations," as Thomas Friedman (2016) calls it - a period in which converging forces accelerate the depth and pace of change. If our society experiences multiple paradigm shifts in a single generation, and the combined effect of those shifts dramatically changes the way that we live, learn, and work, then the phrase, "change is the new normal," is an understatement. We are living in an accelerated time, where change is not just an addition to our life but is a multiplying factor. Change is happening at a faster pace, increasing our ability to do certain things that were not possible even twenty years ago, and complicating our lives exponentially in other ways. We are truly living in a new world.

These broader forces of change provide the background and context for what is happening in theological schools. We are seeing changes in the organizational/financial model of schools, in the diverse models and practices employed, and in the changing nature of ATS student bodies. It is to these more specific changes within theological education that we now turn.

\section{The Shifting Organizational and Financial Model}

At all levels, graduate theological education is changing. As I argued above, the parameters of these changes have deeper currents in the broader forces related to religious participation in North America and higher education. There are many examples of how theological schools are seeking to build economies of scale to better execute their missions in more sustainable ways. In fact, ATS recently received a large grant from the Lilly Endowment to research and disseminate findings related to the changing organizational and financial models of schools. The data that I share is prior to the research phase of this project, but informs some of the guiding questions. These trends and data points illustrate the ways in which schools are shifting their models.

Andover Newton Theological Seminary (ANTS) provides an example of how these changes have played out. In the spring of 2019, the Board of Directors of The Association of Theological Schools voted on the request from Andover Newton to withdraw from membership. Andover Theological Seminary was founded in 1807. It was not only the oldest seminary but the oldest graduate school in the United States. Due to ongoing enrollment and deferred maintenance challenges, the school's board and administration had for several years invested time into the exploration of affiliations and partnerships so that the historical mission of the school could be carried out for future generations in more sustainable ways. Andover's merger with Yale Divinity School (YDS) was made final in July of 2017 after two years of working on the affiliation agreement and implementation. The school is now known as Andover Newton Seminary at Yale Divinity School. It is no longer a free-standing seminary but is now an embedded school at YDS. Andover will continue its distinctive mission, while Yale will be the degree-granting institution. Some within the public view mergers as a next resort to closing. However, this move was clearly a significant advancement for Andover in that it shifted their financial and organizational model in ways that provide a sustainable future for the historical mission of the seminary.

The Andover and Yale merger is more than symbolically important in that it signifies the changing nature of theological schools in the twenty-first century. The fact that the first seminary in the U.S. merged with another prominent academic institution like Yale Divinity School made this agreement newsworthy to the broader public and fed the broader narrative of changes in higher education. Of course Andover Newton, like many other seminaries, was itself the product of a merger in 1965 between Andover Theological Seminary and Newton Theological Institution. The 2017 merger is not a sign of things to come for all theological schools but of an already shifting landscape within seminary education as schools seek greater vitality in their mission and more sustainable financial models for the future.

Since 2009, there have been approximately thirty mergers or affiliations among ATS schools. ${ }^{8}$ Over 10 percent of the 276

8 The information on merged schools was originally compiled by Tom Tanner, Director of Accreditation at ATS. The number of schools varies based on two factors: (1) whether the number includes only accredited schools with the Commission on Accrediting (COA); and (2) there are multiple mergers that are almost complete but have not been made public. The number is currently twenty-seven to twenty-eight ATS schools based on public information with at least another two schools that have not gone public with their announcement at the writing of this article. 
member schools have merged in a decade or, on average, a merger every three to four months. Mainline Protestant schools were involved in the majority of these institutional partnerships, representing just over 60 percent of the total. This over-representation (mainline schools represent approximately 34 percent of the membership) is not surprising given the fact that these schools have faced the most significant enrollment declines during this same period.

One could argue that mergers have been part of the history of theological schools for over a century. In decades where student populations and budgets are leaner, schools tend to consolidate. However, the rate at which theological schools are merging within the past decade suggests that this period of consolidation, particularly among mainline Protestant schools, is more extensive than in years past. This merger trend, along with the declines in religious participation, point to a larger consolidation within Christianity in the U.S. and Canada. ${ }^{9}$

Mergers are only one illustration of how theological schools are seeking to shift their financial and organization models. Other examples include: decreasing or shifting the property footprint of a campus; school relocations; centralizing extension campuses; shared-service agreements among multiple schools; shared faculty positions; and even the use of a subscription-based fee structure instead of a traditional tuition-based model. ${ }^{10}$

One other set of statistics points to the shifting character of the membership among ATS schools. For most of its one hundred years, ATS has been a predominantly mainline Protestant organization. Roman Catholic schools joined ATS in the mid 1960 s to 1970 , the decade following Vatican II. In the last two decades of the twentieth century and the first decade of the twenty-first century, evangelical Protestant schools began to outnumber mainline Protestants. Currently, 44 percent of ATS accredited schools are evangelical Protestant, 34 percent are mainline Protestant, and 22 percent are Roman Catholic or Orthodox. There is one Jewish school in the ATS. ${ }^{11}$ The total number of schools only paints part of the picture. Sixty-five percent of all ATS students attend an evangelical school. In fact, the top twenty schools by enrollment are all within the evangelical ecclesial family. By contrast, of the twenty schools with the largest endowments, sixteen are mainline Protestant. The endowments within mainline schools and the enrollments with evangelical schools point to differing financial models. In the former, a significant portion of the school's revenue comes from its invested assets; in the latter, the model for this group of schools is predominantly tuition-driven.

\section{The Shifting Educational Models and Practices}

If the economic and organizational models of theological education are multiple, the educational practices, with which the schools seek to carry out their mission, are also legion. The ATS, in a landmark study funded through a grant from the Lilly Endowment, surveyed current and emerging educational models and practices within member schools. ${ }^{12}$ This project engaged ninety percent of the membership through research, study groups, conferences, and work groups. The findings show remarkable creativity within the schools and point to new modes of educational practice within theological education, including significant ways that schools are thinking about traditional and well-established models of teaching and learning. In one of the phases of the project, schools met in one of eighteen peer groups. These groups included: ${ }^{13}$

- $\quad$ Formation in Online Contexts

- $\quad$ Educational Values of Online Education

- $\quad$ Duration (Reduced Credit MDiv)

- $\quad$ Accelerated Bachelor's/MDiv

- $\quad$ DMin Admission

9 It must be noted that while mergers have increased over the past decade, there have also been more ATS schools accepted into membership. A high percentage of these schools are smaller and have specific missions based on the student populations whom they serve (for example, a seminary on the West Coast that educates in Mandarin). In 2000 , there were 243 schools in the ATS. The membership is currently at 276.

10 Sioux Falls Seminary currently uses a subscription model for their tuition. Instead of paying by the unit or hour, students pay a flat fee per month to participate in a competency-based degree program.

11 At its last biennial meeting in 2018, the ATS membership voted to accept the Academy for Jewish Religion into membership. It is currently the only Jewish school within associate membership, the category of schools that can move toward accredited status. By charter, ATS is a Judeo-Christian organization and has had Jewish member schools in the past.

12 For a summary report of the findings, see Graham (2018).

13 For a list of the schools that participated in these peer groups, see Graham et al. (2018). 
- DMin Identity

- $\quad$ Permanent Diaconate Program

- $\quad$ Roman Catholic Schools Formation of Laity

- $\quad$ Programs for Latino/a Students

- $\quad$ Global Partnerships (two groups)

- Asian Schools

- Historically Black Schools

- Competency-Based Education

- $\quad$ Programs in Prison

- $\quad$ Students without Bachelor's (Degrees)

- $\quad$ Residential Theological Education

- University Divinity Schools

While most of these peer groups represent theological education to particular audiences (racial/ethnic students, students without a BA, deacons or laity, and so forth), the groups were also brought together by characteristics of their institutional mission (Historically Black Schools and University Divinity Schools), various modalities of educational practice (for example, online, competency-based education, and residential), and different contexts for theological education (global and prisons). In summary, theological schools are finding new and creative models to execute their educational missions as they seek to serve increasingly diverse student populations within various contexts. The schools, through the implementation of these educational models and practices, are generating signature pedagogies based on factors such as the diverse students whom they are teaching, the contexts within which education happens, the use of technology, and the mode of educational delivery. Hence, in a time of significant financial and enrollment challenges, theological schools are becoming increasingly creative and innovative.

To get a better understanding of how schools are innovating their educational missions, it will be helpful to examine two themes, technology and formation, that cut across these various educational models. ${ }^{14}$ There are other themes that have emerged from the study, such as the shifting contexts of education, the commitment to differing forms of quality, and the generating of access for non-traditional students. However, the use of technology, particularly in distance education, and the ongoing need to rethink student formation illustrate well the conversations around emerging educational practices. Digital technologies, and their application within distance learning, have certainly had a substantial impact on theological education specifically and in higher education generally. In theological education, these practices have also shifted how faculty and schools think about the formation of their students. These cross-cutting themes illustrate the dynamics of change that are happening within schools at the teaching level and have contributed to increased debate about the means and ends of theological education. While it is tempting to think of the first of these themes, distance learning, as a technical shift and the second, formation, as a more adaptive and developmental process, I will suggest that both lead to greater adaptive processes for faculty as they reimagine ways of structuring education. Moreover, these two themes, like many of the emerging educational models and practices, often work interdependently within a school's broader culture shift.

\section{Technology}

In their book, That Used to Be Us: How America Fell Behind in the World It Invented and How We Can Come Back (2010), Thomas Friedman and Michael Mandelbaum capture how the world has changed with the advent of digital technologies: “In 2005, Facebook didn’t exist for most people. Twitter was still a sound, the cloud was something in the sky, $3 \mathrm{G}$ was a parking space, applications were what you sent to colleges, and Skype was a typo" $(2010,59)$. Less than fifteen years ago, the idea of a president tweeting out thoughts that could impact world economies was not within the realm of possibility. Even this quote betrays how quickly technology changes. Third

14 For a more comprehensive evaluation of some themes that have emerged in the ATS Educational Models and Practices project, see Graham (2018). 
generation networks $(3 \mathrm{G})$ were quickly replaced with $4 \mathrm{G}$ and now LTE networks, which have speeds up to ten times faster. LTE technology will soon be surpassed by networks that can handle greater speeds and more capacity. Digital technologies are at the heart of the paradigm shift that we have all experienced within the past two decades, and this shift, like many other shifts in the twenty-first century, are accelerating the pace and depth of change in life, business, and education.

Technology, particularly the use of digital technologies in higher education, has changed the ways that teachers teach and students learn. Perhaps the greatest impact has come through online or distance education. ${ }^{15}$ Recent data provide a wide-angle glimpse of how these changes are taking root in theological schools. Twenty years ago, the first ATS schools were approved by the Commission on Accrediting to offer degree programs mostly online. Prior to that no accredited theological school had offered a full course through distance learning. A decade ago, no school was offering a degree program completely online. The number of online courses and degree programs has grown quickly in the last ten years. Recognizing this, the standards for accreditation were revised in 2012 to address the increasing demand for distance learning. Currently, almost two-thirds of ATS schools offer courses online. And over 25 percent have degree programs delivered entirely through distance learning. In 2006-2007, there were less than eight thousand students who had taken at least one course online. Today, that number has tripled to over twenty-five thousand. These numbers will increase since over 140 ATS schools (over 50 percent of the membership) since 2012 have been approved for comprehensive distance education (Tanner 2017a).

While these data point to the dramatic increased usage of distance learning among ATS schools and faculty, they do not tell the full story of the impact that these changes have had on the teaching cultures within seminary faculties. While many current faculty members are familiar with the use of digital technologies, most were not trained to teach courses that are exclusively online. ${ }^{16}$ Underlying these statistics are countless stories of how individuals, academic deans, and faculties have had to unlearn much of what they knew about teaching in order to meet the obvious demand that a large sector of prospective students have come to expect from education based on their previous undergraduate or professional development experiences.

It is beyond the scope of this present article to outline the various processes that have led to successful implementations of comprehensive distance learning programs. However, research on the topic has pointed to some consensus on some of the outcomes and issues, for example:

- When online education is done well, it can lead to deeper conversations about pedagogy, instructional design, and desired student outcomes (Miller and Scharen 2017, 27-28). Case after case within faculties demonstrates that one of the biggest positive outcomes of implementing distance learning within a curriculum is the pause that faculty take to reassess the "why" of their teaching. This has led to more robust and successful online courses and programs while enhancing the teaching that takes place in a traditional face-to-face classroom environment.

- Intentional professional development for faculty is key. One conclusion that came from the Educational Models and Practices project (Association of Theological Schools 2018) was that faculty, often viewed by boards and administrators as resistant to change, demonstrated remarkable adaptability when the right processes and investments were made into training them to do this new type of teaching and learning well. Faculty were educated and trained within an intellectual, expert model of professionalism. They were not taught to experiment, to "try things on," or to relearn how they teach. Having the right resources and processes in place to structure these culture shifts for faculty is critical to the success of any new program, online or otherwise.

- $\quad$ Development of online courses and programs takes time. When they incentivize online teaching, academic deans often resource their faculties to take courses on how to teach in distance learning formats and/or offer course releases to allow for the development of a new online course. Teaching an online course usually takes about 50 percent more time both to design it and to teach it (Miller and Scharen 2017, 28-29).

\footnotetext{
15 I am using the terms "online" and "distance" interchangeably, though there is a distinction between these terms in the literature. Online education focuses on any form of educational practice that utilizes online resources. Thus, the use of a learning management system with digital resources is technically online education. Distance education is a form of learning that seeks to overcome geographical distance between teachers and students and between students and other students. Another often used phrase, "distributed learning," uses multiple forms of media so that learning can take place independent of both space and time (for example, synchronous and asynchronous models or self-paced courses). The ATS Standards of Accreditation, in the Educational Standards, employ the language of "distance education" (2015).

16 When academic deans were surveyed about the challenges with online learning, the most frequent response (6o percent of those surveyed) was the adaptive challenge to train faculty for online teaching (Tanner 2017b). See also Miller and Scharen (2017).
} 
- $\quad$ Because of the attention to design, pedagogy, and learning objectives, the student learning outcomes from distance learning is equal to or better than traditional, residential models of education. This is not to say that learning online is superior to learning in the classroom. However, what we might be learning about distance education is that it, like any educational innovation, has the potential to improve the quality of teaching and learning with proper attention to design and rigorous assessment of the ends of education.

This is not a defense of or advocacy for distance learning in theological education. However, it is hard to emphasize enough that theological education is in the middle of a major shift in the way that teaching and learning happens in schools. The data bear out that distance learning is an increasingly used educational modality among ATS schools. Moreover, best practices suggest that this form of education is not simply a technical fix for schools to increase enrollment but is an adaptive shift for schools as they re-evaluate the purposes and ends of the education that they provide.

\section{Formation}

Dan Aleshire has argued that theological education is currently undergoing its third significant shift in emphasis and identity. Theological education, in the early colonial years of the United States, was primarily developed around two models, the learned clergy or formal education model and the apprenticeship model. In the twentieth century, with the growth of free-standing, mainline Protestant seminaries, the professional model became the dominant form of training for religious leadership. This model, equipped with theological fields of expertise, stressed the professional development of mostly young men in order to equip them to serve in the vocations to which they were called. Aleshire believes that we are currently in a third wave, formational theological education, which has precedent in Roman Catholic priestly preparation $(2018,25-37)$. This is not to say that this theme of formation will take on a single, dominant form. As I argued earlier, one of the things that characterizes twenty-first century theological education is its diversity. However, the theme of formation is emerging in many forms and contexts, across the theological spectrum, and among all of the ecclesial families. With the fragmenting and de-centralization of religious institutions, the need to emphasize the multiple dimensions of religious formation generally and vocational formation specifically has become critical to the work of theological schools. ${ }^{17}$

The theme of formation came up in most of the peer groups that met to discuss current educational models and practices through ATS' most recent initiative. Stephen Graham, who directed this Lilly Endowment funded project, concluded in his summary that the groups, representing these various educational practices, "argued that theological education is 'inherently formational,' perhaps in ways that exceed the formational aspects of other forms of graduate professional education" (Graham 2018, 7-9). Tom Tanner concurs from his perspective as an accrediting director:

while formation may defy simple definitions, it is still held in high regard by the membership, regardless of delivery, degree, or student demographic. Since their initial implementation in 1938, our standards have tended to treat theological education primarily as a profession. As ATS enters its second century, the next set of standards may need to focus more on formation as an overarching goal of theological education. $(2018,2)$

Whether in online formats, residential models, or in modes of education like competency-based education, the theme of contextualized formation is central when discussing the objectives of theological education.

The topic of formation becomes more important and complex when one takes into account the ways in which religious vocations have shifted in recent decades. With the de-centering of religious institutions in North American public life, communities of faith are no longer carrying out the same functions within society. For this reason, graduates of ATS schools are increasingly serving in more diverse contexts that handle work that used to be located in communities of faith. A recent survey of ATS alumni/ae found, that while the plurality (41 percent) still serves in congregational settings, the majority (59 percent) serve in a variety of contexts outside of congregations. Sectors, in which ATS graduates are serving, include: education (38 percent of those serving outside of congregations); faith-related organizations (14 percent); health care, for example, chaplains and counselors (12 percent); community service (8 percent); denominational administration (7 percent); and other (15 percent). Another 6 percent were either unemployed or had an unknown vocational setting. From these data, Jo Ann Deasy concludes:

ATS schools. . . will need to wrestle with the relationship between theological education and these diverse work settings. They will need to redefine or reconfirm mission and consider the implications for curriculum and

\footnotetext{
17 For a discussion of the four classical areas of Roman Catholic formation - human, spiritual, intellectual, and pastoral - rooted in the ecclesial vision of Pope Francis, see Senior $(2019,62-65)$.
} 
degree programs. And they will need to continue listening to their students and alums as they navigate the changing landscape of ministry in the United States and Canada. (2018, 4)

Thus, formation of students must take into account the diverse roles and contexts in which seminary graduates are serving. We are seeing the decentralization of religious vocations as graduates of theological education are moving into areas of work and service beyond the walls of the traditional congregation. We are witnessing the redefinition of ministry.

In all of these vocational settings, the competencies required for graduates to effectively do their work is also becoming more diverse and complex. The same alumni/ae survey asked graduates for the competencies required for them to best fulfill their work responsibilities (Gin 2018). While a cluster of the top responses reflect current emphases within theological curricula and traditional ministry settings, there are an increasing number of competencies that relate to the diverse contexts in which graduates now do their work. For example, the most frequently named competency listed in the survey was administration. While administration is certainly a significant part of congregational leadership, its place at the top of listed competencies represents a shift in emphasis for religious leaders. Along with competencies such as spiritual disciplines, theology, pastoral care and counseling, and preaching, alums also named interpersonal competency, finance, conflict resolution, intercultural competency, active listening, and having difficult conversations (Gin 2018, 1). This list demonstrates not just a shift in the character of work that theological graduates carry out, it also points to the changing character of work within congregations. In the context of formation, Debbie Gin reflects on how a school can attend to the competencies required for twenty-first century religious vocations: "Finding out where alums are working, with what job titles and contexts, and connecting with those who partner in preparing students for those jobs are two great places to start” (Gin 2018, 4). In other words, theological schools must think about their specific role within the longer journey of a student's spiritual, intellectual, human, and vocational formation.

Both distance learning and formation point to the broader cultural and adaptive shifts that are currently at work within theological schools. Digital technology, and its implementation into theological curricula, is not simply a new platform to do education as we have traditionally understood it. The building of a distance learning program is better viewed as an adaptive process that seeks to improve the quality and accessibility of education for the twenty-first century student. Formation is not just the practical side of the more theoretical theological disciplines, relegated to courses in field education. It is a larger developmental process that will require a school to adapt its practices and engagement with students and alums in such a way that helps them to succeed within the diverse vocations that they seek.

These two themes within emerging educational practices also intersect with each other. For example, one of the peer groups for the Educational Models and Practices project looked specifically at the idea of formation in online contexts (Graham et al. 2018). ${ }^{18}$ While the question of student formation is at the top of the list of challenges for distance education programs, this peer group also named substantial benefits that online education provides for formation. For example, distance education opens up the opportunity for the student's current ministry and life context to become a fertile ground in which learning can take root. Online learning also can facilitate cross-cultural engagement, particularly with international students, while eliminating or dramatically reducing relocation costs. Students frequently comment about how an online degree program provides increased flexibility and greater access to education. Thus, distance education is broadening and deepening the contextual nature of theological education. Context has always mattered in the training of religious leadership; but online learning has expanded the possibilities for a learning community and has foregrounded the need to engage the multiple contexts in which students live and serve.

\section{The Shifting Student Populations}

If the educational models and practices of theological schools are becoming increasingly diverse and interdependent, so too are the students that theological schools are serving. This increase in student diversity is a driving force behind many of the educational innovations described above and points to an important emerging edge for the future of theological pedagogical practices.

Demographers believe that by the year 2040, or somewhere in the middle decades of the twenty-first century, the United States will have no single racial-ethnic majority. This does not mean that racial prejudice or institutional racism will cease to exist. In fact, if the past decade is any indication, racial tensions and social unrest around the issue of race, especially in the United States, will continue to increase. We see evidence that these demographic changes within the broader population are tracking within ATS schools.

African American, Latino/a, Asian and Asian North American, and international students have increased collectively from 30 percent to 45

18 On formation in online contexts, see also Hess (2007) and Blier (2007). 
percent of the total of ATS students over the past twenty years. Moreover, more than 20 percent of ATS schools already have a majority of racial/ethnic presence in their student populations. Thus, at the current rate of growth, ATS schools will have 2040 demographics among their students decades ahead of the general population. Faculty diversity is also growing but at a slower rate than that among students. Twenty percent of full-time faculty in theological schools are faculty of color, which is up from 10 percent twenty years ago. These demographic realities are also represented differently among the ecclesial families. Historically, the largest group of racial-ethnic students in mainline Protestant schools are African Americans, in evangelical Protestant schools, Asian and Asian North Americans, and in Roman Catholic schools, Latino/a students.

To address these growing demographic realities, many ATS schools have shifted their educational practices. One of the major themes from the previously mentioned Educational Models and Practices project was student and institutional development in cultural competency "to serve increasingly culturally diverse communities, both in North American and around the globe" (Graham 2018, 2). In Canada, which understands the construction of race differently than the U.S., some theological schools have sought to respond to the work of the Truth and Reconciliation Commission. This Commission issued ninety-four calls to action that sought to address the harmful legacy of Canadian education on indigenous peoples and to provide specific ways to move toward reconciliation. ${ }^{19}$ In this way, theological schools are both looking backward and forward. They are seeking to address the legacies of racial injustices from the past, while they are developing pedagogical and formational practices for their more diverse student populations in the present and future. All of these practices suggest that demographic diversity is not enough. Schools are engaging in practices and processes to adapt to new realities and to address harmful legacies.

Through most of the twentieth century, a seminary student was typically white or European American, male, younger, full-time, residential, in an MDiv degree program, and was attending a school of the same denomination in which the student was raised. A denomination or a local congregation usually supported this seminarian financially, and the student would go on to serve a congregation within that same denomination. The twenty-first century theological student is different on almost every front. He or she is increasingly a person of color, older, part-time, a local commuter, an MA student, and is often attending a school that is closer in geographic proximity and not necessarily of the same religious heritage. The student is primarily responsible for financing his or her theological education and is often already engaged in a local ministry context while working on a degree. This characterization of the twenty-first century student emerges from the larger social and educational trends discussed above. Moreover, the educational innovations that have fueled the creative work of theological schools within the past two decades are directly related to these changes in the makeup of their student populations. If the whole ecology of religious and theological education is shifting due to broader social forces, then the themes provided in this article are descriptive effects of a system that is dynamic and decentralizing. In other words, change is the new normal for theological schools.

\section{Conclusion: Contours of Teaching and Learning for the Present and Future}

In this article, I have sought to provide the larger contexts of change that are affecting theological education. In order to explore the possible implications of these dynamics on teaching and learning, I will briefly propose four themes, which have emerged from the presentation above, that will inform teaching and learning in theology and religion both now and in the decades to come. Those four themes are diversity, context, formation, and the changing nature of faculty work.

The future of theological education will be defined by its diversity or plurality. There are many components to this diversity. There is a descriptive component. That is, no one model of teaching and learning will dominate the landscape. Moreover, the students are more demographically diverse, the contexts from which they come are increasingly culturally complex, and the modes in which they are learning are multiple. The implications for teaching and learning are clear. There is no one-size-fits-all model for education. Future teaching strategies must be able to account for the increasing diversity of students while engaging in multiple forms of education to better achieve appropriate learning goals. As argued above, the process of developing these new forms is just as important. Attention to what counts for good education, identifying the assumed value that emerges from particular educational practices, and focusing on the desired outcomes will help to shift the teaching cultures of theological faculty.

Related to the multiple diversities among the students of theological education is a renewed emphasis on the importance of context. Context has always been an important factor in theological education; but the nuances have shifted in recent decades. For example, among theological schools, and within the current accrediting standards, there is an assumption that formation is tied to a residential mode of education. Certainly, formation and educational community can benefit from being in one place. However, students are increasingly doing their theological education while they are already serving in ministry or other vocational contexts, and a larger percentage of students are

19 For more on the Calls to Action, see Truth and Reconciliation Commission of Canada (2015). 
local commuters. Moreover, in distance learning contexts, the student's community is often removed from campus life. In these cases, faculty and on-site mentors often use the local ministry or community context to enhance the educational experience of the student. In competency-based theological education, schools have engaged with local congregations and/or denominational bodies to explore the contextual leadership capacities required to serve in these communities. Competencies are identified and curricula are developed with deep engagement to the context of congregations and communities of faith. These examples share the common theme of pedagogical practices that take into account the importance of context, even when students' contexts are increasingly multiple and complex.

Theological schools will continue to invest in the formation of both students and faculty. The need to attend to students' ongoing spiritual, human, intellectual, and pastoral/vocational formation will be a continual emphasis in the pedagogies of the next decades. With the decreasing amount of broader religious formation happening in the earlier stages of human development, theological schools will continue to play a vital role in forming the religious leadership and practitioners of the future. Because education is in such a dramatic period of change, faculty formation will also continue to play a strong role in the future of theological education. Doctoral programs contribute most to the forming of future faculty as scholars, and to a smaller degree, as teachers. Increasingly faculty will have to be trained to utilize new technologies, to rethink teaching strategies, and to structure learning outcomes in new ways for twenty-first century students. In this way, both faculty and students will be formed for the religious institutions of the future, which will be more dynamic and in various stages of change.

The increasing portfolio for religious faculties points to another dynamic in the current landscape - the changing nature of faculty work. In a recent presentation to a group of ATS schools, Debbie Gin shared the results from a survey of theological school faculty. ${ }^{20}$ In this survey, faculty were asked for the most important aspects of their work, how well their doctoral programs trained them for these aspects, and how adequately their current institutions provided professional development for these areas. Three of the top five responses - teaching, research, and service - were typical, and both doctoral programs and current school employers provided some training in these areas. However, two of the five - formation of students and administrative work - were graded negatively by faculty, meaning that their doctoral work and their institution do not provide enough support in these emerging areas of work. Administratively, faculty are increasingly called upon to develop new programs, to run centers, and to provide administrative support for the school's educational mission (for example, student learning assessment, administration in a field education program, oversight of a degree program, and so forth). In this way, the vocational identity of faculty is changing. Faculty are not just scholars and teachers. They can also be administrators, formentors, and program developers.

The changing nature of work described above will require a different set of skills and dispositions from faculties of theological schools. Two are worth mentioning: adaptability and experimentation. ${ }^{21}$ In a time when institutions are more dynamic, faculty members are better positioned to succeed when they foster habits of adaptability. Being adaptable is a discipline as fields such as improvisational comedy or jazz performance demonstrate. A quality lead on the saxophone does not just happen spontaneously. Thousands of hours of practice with one's instrument and colleagues goes into that improvisational moment. Jazz musicians learn to listen deeply and agilely to their fellow musicians, to the music as a whole, and to the energy in the audience. Being adaptable can be an innate quality of an individual, but it can also be an acquired skill. The ability for a school to be able to pivot quickly in response to its changing environment is directly related to the ability of its faculty and administrators to be adaptable.

Similarly, experimentation is a process that most faculty have not engaged in consistently. For example, in new program creation, schools have tended to over-develop programs without much engagement of the intended audience. In this way, new programs are thought up in ways similar to the writing of a book. Much of the process is internal to the creator(s) without sustained feedback from those outside of the development process. In his book The Lean Startup (2011), Eric Reis, who comes from the technology startup world, encourages the use of MVPs or minimally viable products. An MVP is a prototype, which captures enough of a vision of the product so that users see its potential. More importantly, part of the developmental process includes the testing out of the developer's assumptions as individuals use the product in tests or experiments to accomplish work (or play). The MVP process creates a learning loop that then helps the designers to better develop their product for the end user based on feedback from experiments.

Experimentation could inform the teaching and learning process within theological schools. For example, before a degree program is approved for accreditation and marketing, faculty could develop certificate programs (ATS does not accredit certificates) based on inputs from prospective student audiences. The certificates could also experiment with technology or an under-utilized modality of education to see if it provides greater access, quality, or engagement to learning communities. As assumptions get confirmed or challenged through feedback, the pilot can be further designed to improve its potential to deliver a quality educational experience.

20 Deborah Gin was one of six presenters from ATS staff in the presentation, “Top Enrollment Schools, ATS Schools: A State of the Industry”( Gin et al. 2019).

21 Juan Martinez (2018) argues that an important aspect of the future of theological education involves the preparation of leaders to be more adaptive and experimental. 
Dan Aleshire, who served as Executive Director of ATS for two decades, used to say that theological schools are conservative by nature. They are not institutions that are primed to be agile in times of challenge. The research on ATS schools and faculty over the past two decades both reaffirms this truism and challenges it. Theological schools may change with difficulty, but they are changing in rapid and profound ways. We are seeing evidence of these changes in every aspect that makes up a school - the organizational model, the educational practices, and among the students whom they serve. Schools are adapting within the broader shifts of the changing landscape of both religious communities and higher education in North America. These are the larger forces of change that will determine the future work of faculty; and it is these trends that provide the context and will determine the future shape of teaching and learning in theology and religion.

\section{BIBLIOGRAPHY}

Aleshire, Daniel O. 2018. “The Emerging Model of Formational Theological Education.” Theological Education 51 (2): $25-37$. https://www.ats.edu/uploads/resources/publications-presentations/theological-education/2018-theological-education-v51-n2.pdf.

Association of Theological Schools, Commission on Accrediting. 2018. "Educational Models and Practices in Theological Education Peer Groups." https://www.ats.edu/uploads/resources/current-initiatives/educational-models/publications-and-presentations/listing-of-peer-groups.pdf.

Association of Theological Schools. 2015. Commission on Accrediting: Educational Standards. https://www.ats.edu/uploads/accrediting/documents/educational-standard.pdf.

Blier, Helen M. 2007. “Webbing the Common Good: Viritual Environment, Incarnated Community, and Education for the Reign of God." Teaching Theology and Religion 11 (1): 24-31.

Burge, Ryan P. 2019. “Evangelicals Show No Decline, Despite Trump and Nones.” Christianity Today, March 21. https://www.christianitytoday.com/news/2019/march/evangelical-nones-mainline-us-general-social-survey-gss.html.

Chaves, Mark. 2017. American Religion: Contemporary Trends. Princeton, NJ: Princeton University Press.

Christensen, Clayton. 2011. The Innovative University: Changing the DNA of Higher Education from the Inside Out. San Francisco, CA: Jossey-Bass.

Clarke, Brian, and Stuart Macdonald. 2017. Leaving Christianity: Changing Allegiances in Canada since 1945. Chicago, IL: McGill-Queen's University Press.

Deasy, Jo Ann. 2018. “Where Are Graduates Serving? New Insights from the Educational Models Alums Workforce Survey.” Colloquy Online, April. Association of Theological Schools, Commission on Accrediting. https://www.ats.edu/uploads/resources/ publications-presentations/colloquy-online/where-are-the-alums-serving.pdf.

Friedman, Thomas L., and Michael Mandelbaum. 2010. That Used to Be Us: How America Fell Behind in the World It Invented and How We Can Come Back. New York, NY: Farrar, Straus, and Giroux.

Friedman, Thomas. 2016. Thank You for Being Late: An Optimist's Guide to Thriving in the Age of Accelerations. New York, NY: Picador.

Gin, Deborah H. 2018. “Mapping the Workforce: What Competencies Do ATS Alums Need?” Colloquy Online, September. Associ- 
ation of Theological Schools, Commission on Accrediting. https://www.ats.edu/uploads/resources/publications-presentations/colloquy-online/mapping-the-workforce.pdf.

Gin, Deborah H., et al. 2019. "Top Enrollment Schools, ATS Schools: A State of the Industry.” Association of Theological Schools. Presented on March 27, 2019 in Pittsburgh, PA.

Graham, Stephen R. 2018. "Educational Models and Practices in Theological Education: Summary Reflections on Final Peer Group Reports." Association of Theological Schools, Commission on Accrediting. https://www.ats.edu/uploads/resources/current-initiatives/economic-challenges-facing-future-ministers/emp-peer-group-reflections.pdf.

Graham, Stephen R., et al. 2018. "Educational Models and Practices Peer Group Final Reports." Association of Theological Schools, Commission on Accrediting. https://www.ats.edu/uploads/resources/publications-presentations/theological-education/2018-theological-education-v51-n2.pdf.

Hess, Lisa M. 2007. "Formation in the Worlds of Theological Education: Moving from 'What' to 'How.' Teaching Theology and Religion 11 (1): 14-23.

Hudnut-Beumler, James, and Mark Silk. 2018. The Future of Mainline Protestantism. The Future of Religion in America Series 2. New York, NY: Columbia University Press.

Lipka, Mike. 2015. “Millennials Increasingly Are Driving Growth of 'Nones.” Pew Research Center: Fact Tank, May 12. http://pewrsr. ch/1 $\mathrm{H}_{1} \mathrm{XH}_{3}$.

Martinez, Juan Francisco. 2018. “Preparing Leaders for God's Work in a World of Adaptive Challenge.” Theological Education 51 (2): 11-18. https://www.ats.edu/uploads/resources/publications-presentations/theological-education/2018-theological-education-v51-n2.pdf.

Miller, Sharon L., and Christian Scharen. 2017. "Not Being There: Online Distance Theological Education." Auburn Studies 23. https://auburnseminary.org/report/not-being-there/.

Pew Research Center. 2015. “America’s Changing Religious Landscape.” Pew Research Center: Religion \& Public Life. https://www. pewforum.org/2015/05/12/americas-changing-religious-landscape/.

Ries, Eric. 2011. The Lean Startup: How Today's Entrepreneurs Use Continuous Innovation to Create Radically Successful Businesses. New York, NY: Crown Business.

Senior, Donald. 2019. "The Ecclesial Vision of Pope Francis and the Future of Catholic Theological Education." In Disruption and Hope: Religious Traditions and the Future of Theological Education, 62-65. Waco, TX: Baylor University Press.

Smith, Ted A., Marti R. Jewell, and S. Steve Kang. 2018. "A Special Issue with Essays from Theological Education: Between the Times." Theological Education 51 (2): 1-9. https://www.ats.edu/uploads/resources/publications-presentations/theological-education/2018-theological-education-v51-n2.pdf.

Tanner, Tom. 2017a. "Online Learning at ATS Schools: Part 1 - Looking Back at Our Past." Association of Theological Schools, Commission on Accrediting. https://www.ats.edu/uploads/resources/publications-presentations/colloquy-online/online-learning-part-1.pdf. 
Tanner, Tom. 2017b. “Online Learning at ATS Schools: Part 2 - Looking Around at Our Present.” Association of Theological Schools, Commission on Accrediting. https://www.ats.edu/uploads/resources/publications-presentations/colloquy-online/ online-learning-part-2.pdf.

Tanner, Tom. 2018. "Reflections on Key Themes and Principles from ATS Peer Groups for the Redevelopment of the ATS Standards and Procedures." Association of Theological Schools, Commission on Accrediting. https://www.ats.edu/uploads/resources/ current-initiatives/economic-challenges-facing-future-ministers/peer-group-reports-themes-and-principles.pdf.

Truth and Reconciliation Commission of Canada. 2015. "Truth and Reconciliation Commission: Calls to Action." http://nctr.ca/ assets/reports/Calls_to_Action_English2.pdf.

\section{ABOUT THE AUTHOR}

Frank Yamada is the sixth executive director of The Association of Theological Schools. He brings to this role years of leadership experience in theological education and in communities of faith. Before coming to ATS, he was the tenth president of McCormick Theological Seminary in Chicago and was an active Hebrew Bible scholar with a focus on cross-cultural and feminist hermeneutics. 